\title{
Perfluorochemicals 浸漬法による
}

\section{心筋保護効果の実験的検討}

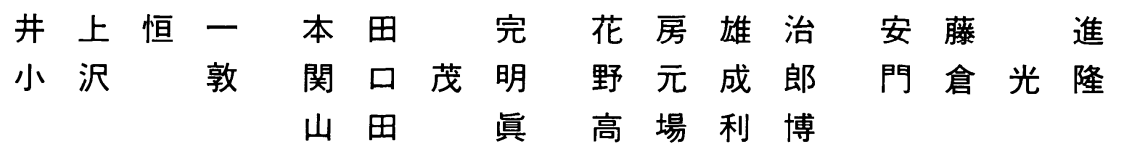

\begin{abstract}
心臓手術における心筋局所冷却法は有効な心筋保護法であるが心囊に氷水を満たすことによる横隔神 経障害, 冠動脈スパズムによる心筋保護液の不均等供給などの問題も存在する. これらの冷却障害を 回避するため心筋冷却を軽度とし, 増大する心筋酸素需要に対する酸素供給を目的として, 優れた酸 素運搬能を持つPerfluorochemicals (PFC) に心臓を浸漬し，有効性を検討した。 ラット摘出心 (心 筋温 $20^{\circ} \mathrm{C}$ ) での冠灌流遮断実験では, 遮断中 $\mathrm{PFC}$ に浸漬しなかった群の心拍動持続時間は $10 \pm 2$ 分で あったが, PFC 浸漬群は $20 \pm 4$ 分であった。 心筋温 $30^{\circ} \mathrm{C} て ゙$ cardioplegia による急速心停止を得た実 験において, PFCに浸漬した群は非浸漬群および生食水浸漬群より再灌流後の心機能の回復は良好で あった．軽度心筋冷却 $\left(30^{\circ} \mathrm{C}\right)$ 虚血下において PFC に心臓を浸漬した場合，冠循環を介さず心筋に酸 素を供給し心筋保護効果を示したと考えられた。，少外会誌 24 巻 5 号：305-310（1995）

Keywords : Perfluorochemicals, 心筋冷却障害
\end{abstract}

\begin{abstract}
The Myocardial Protection of Immersion Hearts in Perfluorochemicals during Ischemia
Koichi Inoue, Osamu Honda, Yuji Hanabusa, Susumu Ando, Atsushi Ozawa, Shigeaki Sekiguchi, Seiro Nomoto, Mitsutaka Kadokura, Makoto Yamada and Toshihiro Takaba (Department of Surgery, Showa University School of Medicine, Tokyo, Japan)

Topical cardiac hypothermia has unequivocal preservation effects during ischemia, but it has some disadvantages. Topical cooling, especially with ice slush, can injure the phrenic nerve, disturb the equal distribution of the cardioplegic solution due to coronary artery spasm and damage the epicardium. It is easy to prevent cooling injury without topical hypothermia, but the myocardial oxygen demands are increased. In order to supply the myocardium with oxygen for the increased oxygen demands during ischemia, isolated rat hearts were immersed in perfluorochemicals (PFC) which have excellent transportation of oxygen. The effects of immersion in PFC during mild hypothermic ischemia (at $20^{\circ} \mathrm{C}$ without cardioplegia and at $30^{\circ} \mathrm{C}$ cardioplegic arrest) on the cardiac function on reperfusion were evaluated. Under $20^{\circ} \mathrm{C}$ hypothermic ischemia without cardioplegia, cardiac beating was maintained for $20 \pm 4$ minutes in the hearts were immersed in PFC, and for $10 \pm 2$ minutes in the hearts that were not immersed in any solution. In the recovery of cardiac function ( $L V D P$ and $L V_{\max } \mathrm{d} p / \mathrm{d} t$ ) after mild hypothermic $\left(30^{\circ} \mathrm{C}\right)$ cardioplegic arrest, the hearts immersed in PFC showed better results than hearts that were not immersed. Jpn. J. Cardiovasc. Surg. 24 : 305-310 (1995)
\end{abstract}

\footnotetext{
心臓手術時の局所冷却は有効な心筋保護法であ るが, 氷冷生理食塩水や ice slush を心囊に充填す るため過度の冷却が心筋を傷害したり，冠動脈卛 縮を起こして cardioplegia 液の供給を不均等に したりする。さらに心囊に沿って走行する横隔神

1994 年 5 月 26 日受付, 1994 年 12 月 22 日採用

昭和大学外科学教室 $\mathbf{T} 142$ 東京都品川区旗の台 1-5-8

本論文の要旨は, 第 22 回日本心臓血管外科学会学術総会 (1992

年 4 月, 仙台）において発表した。
}

経にも障害を起こすことがある1 3).これらの問題 を回避するために心蔵の冷却を軽度にすれば，心 筋温の上昇に伴う代謝六進が酸素消費を増加さ せ，結果として心筋保護効果を低下させることに なる。 心筋局所冷却を行わない場合, 高エネルギ 一化合物の消耗を抑制するため好気性代謝の維持 が必要である.そこで心筋温上昇による酸素需要 量の増加に対して, 優れた酸素運搬能を有する 
Perfluorochemicals (PFC) に心臓を浸漬し, 非循 環性に心筋への酸素供給が可能であるか実験的に 検討した.

\section{実験方法}

\section{1. 摘出心の作成}

体重 220〜260 g の Wistar 系雄ラットを使用し た. $100 \%$ 酸素化エーテルによる吸入麻酔下にへパ リン $2.5 \mathrm{mg}(2,500$ I. U. ) を静脈内投与し全身へ パリン化した. 開胸後に心肺を一塊として切除し 氷冷へパリン加 Krebs-Henseleit buffer (KHB) 液に浸漬し心拍動を停止させた。

次に肺を切除し胸腺, 食道を除去した後, 上行 大動脈にカニューレを挿入し, 直ちに $90 \mathrm{~cm}$ 水柱 圧で $37^{\circ} \mathrm{C} \mathrm{KHB}$ 液を冠灌流する Langendorff 灌 流装置へ装着し摘出灌流拍動心とした. 開胸心摘 出から冠灌流開始後拍動を再開するまで約 2 分で あった。

\section{2. 灌 流 液}

灌流液は森下製薬製の KHB 液（Krebs-Henseleit bicarbonate buffer) $に 95 \% \mathrm{O}_{2}+5 \% \mathrm{CO}_{2}$

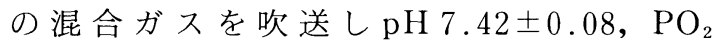
$580 \pm 80 \mathrm{mmHg}, \mathrm{PCO}_{2} 40 \pm 5 \mathrm{mmHg}$ に調整した。 表 1 に組成を示した。

\section{Cardioplegia 液}

Cardioplegia 液は教室で心臓手術の際に臨床 使用している St. Thomas' Hospital solution を 使用した。これも $\mathrm{KHB}$ 液と同様に $95 \% \mathrm{O}_{2}+5 \%$

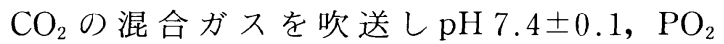
$550 \pm 20 \mathrm{mmHg}, \mathrm{PCO}_{2} 35 \pm 15 \mathrm{mmHg}$ に調整し

表 1 KHB 液の組成

\begin{tabular}{lr}
\hline $\mathrm{NaCl}$ & $118.0 \mathrm{mM} / l$ \\
$\mathrm{KCl}$ & $4.7 \mathrm{mM} / l$ \\
$\mathrm{CaCl}_{2} \cdot 2 \mathrm{H}_{2} \mathrm{O}$ & $2.5 \mathrm{mM} / l$ \\
$\mathrm{MgSO}_{4} \cdot 7 \mathrm{H}_{2} \mathrm{O}$ & $1.2 \mathrm{mM} / l$ \\
$\mathrm{KH}_{2} \mathrm{PO}_{4}$ & $1.2 \mathrm{mM} / l$ \\
$\mathrm{NaHCO}_{3}$ & $25.0 \mathrm{mM} / l$ \\
$\mathrm{Ca}-\mathrm{EDTA}$ & $0.5 \mathrm{mM} / l$ \\
$\mathrm{Glucose}$ & $11.1 \mathrm{mM} / l$ \\
$\mathrm{pH}$ & $7.24 \pm 0.08\left(37^{\circ} \mathrm{C}\right)$ \\
$\mathrm{PO}_{2}$ & $580 \pm 80 \mathrm{mmHg}$ \\
$\mathrm{PCO}_{2}$ & $40 \pm 5 \mathrm{mmHg}$ \\
\hline
\end{tabular}

た。表 2 に組成を示した。

\section{Perfluorochemicals}

大動脈遮断中の心臓に酸素を供給する目的で浸 漬液として使用したPFC は株式会社ミドリ十字 の Fluosol ${ }^{\circledR}$-DA（FDA）に純酸素ガスを吹送し $\mathrm{pH} 7.564 \pm 0.12, \mathrm{PO}_{2} 660 \pm 75 \mathrm{mmHg}, \mathrm{PCO}_{2} 4 \pm 4$ $\mathrm{mmHg}$ に調整して使用した。組成を表 3 に示し た.

\section{5. 実験装置}

装置全体はガラス製二重管構造とし，外側に温 水あるいは冷水を循環させ内側の灌流液を目的温 度に維持した。装置全体の概略を図 1 に示した。 固定された内径 $1.8 \mathrm{~mm}$, 外径 $2.0 \mathrm{~mm}$ のステン レス製大動脈カニューレを上行大動脈へ挿入結禁

表 2 St.Thomas' solution の組成

\begin{tabular}{lr}
\hline $\mathrm{NaCl}$ & $91.6 \mathrm{mM} / l$ \\
$\mathrm{KCl}$ & $14.8 \mathrm{mM} / l$ \\
$\mathrm{CaCl}_{2} \cdot 2 \mathrm{H}_{2} \mathrm{O}$ & $1.2 \mathrm{mM} / l$ \\
$\mathrm{MgSO}_{4} \cdot 7 \mathrm{H}_{2} \mathrm{O}$ & $1.2 \mathrm{mM} / l$ \\
$\mathrm{KH}_{2} \mathrm{PO}_{4}$ & $1.2 \mathrm{mM} / l$ \\
$\mathrm{NaHCO}_{3}$ & $25.0 \mathrm{mM} / l$ \\
$\mathrm{MgCl}_{2} \cdot 6 \mathrm{H}_{2} \mathrm{O}$ & $15.0 \mathrm{mM} / l$ \\
$\mathrm{Procaine}-\mathrm{HCl}$ & $1.0 \mathrm{mM} / l$ \\
$\mathrm{pH}$ & $7.4 \pm 0.1\left(37^{\circ} \mathrm{C}\right)$ \\
$\mathrm{PO}_{2}$ & $550 \pm 20 \mathrm{mmHg}$ \\
$\mathrm{PCO}_{2}$ & $35 \pm 15 \mathrm{mmHg}$ \\
\hline
\end{tabular}

表 3 Fluosol $^{\circledR}$-DA の組成

\section{Perfluorodecalin}

Perfluorotripropylamine

Pluronic F-68

Yolk phosopholipid

Glycerol

$\mathrm{NaCl}$

$\mathrm{KCl}$

$\mathrm{MgCl}_{2}$

$\mathrm{CaCl}_{2}$

$\mathrm{NaHCO}_{3}$

Glucose

Hydroxyethylstarch

$\mathrm{pH}$

$\mathrm{PO}_{2}$

$\mathrm{PCO}_{2}$

Osmolality
$14.0 \mathrm{w} / \mathrm{v} \%$

$6.0 \mathrm{w} / \mathrm{v} \%$

$2.7 \mathrm{w} / \mathrm{v} \%$

$0.4 \mathrm{w} / \mathrm{v} \%$

$0.8 \mathrm{w} / \mathrm{v} \%$

$0.6 \mathrm{w} / \mathrm{v} \%$

$0.034 \mathrm{w} / \mathrm{v} \%$

$0.02 \mathrm{w} / \mathrm{v} \%$

$0.028 \mathrm{w} / \mathrm{v} \%$

$0.21 \mathrm{w} / \mathrm{v} \%$

$0.18 \mathrm{w} / \mathrm{v} \%$

$3.0 \mathrm{w} / \mathrm{v} \%$

$7.564 \pm 0.12\left(37^{\circ} \mathrm{C}\right)$

$660 \pm 75 \mathrm{mmHg}$

$4 \pm 4 \mathrm{mmHg}$

$410 \mathrm{mOsm}$ 


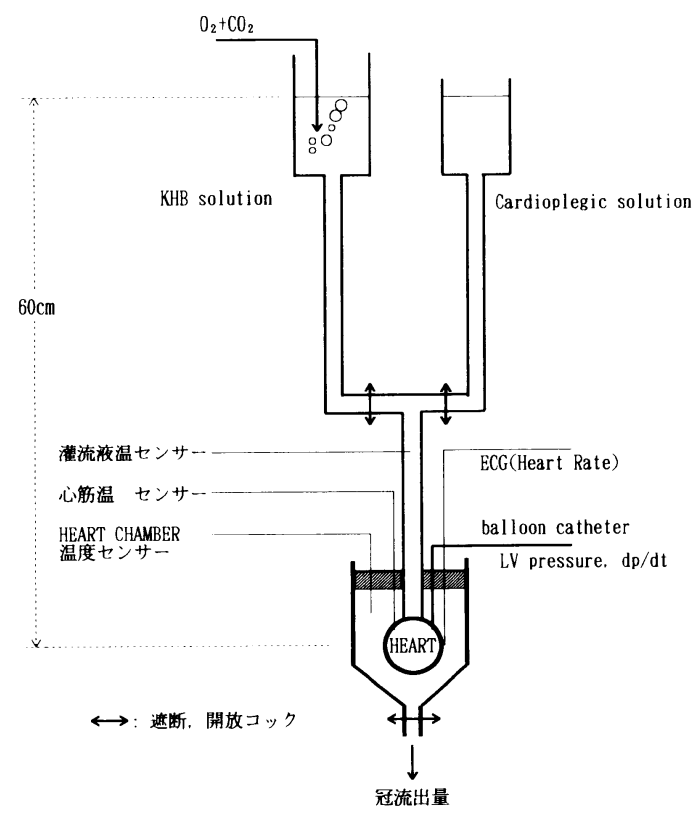

図 1 実験装置概略

し心臓を heart chamber 内へ固定した，Langendorff 冠灌流および cardioplegia 液注入回路は Y 字管で連結しコックで切り換えるようにした。こ の注入圧は両方とも心臟に対して $60 \mathrm{~cm} \mathrm{H}_{2} \mathrm{O}$ と した. 温度センサーを回路内, heart chamber 内, および心筋温として肺動脈から右心室内に置いて 持続的に監視した。心電図電極を右心室流出路前 壁に刺入し心拍数を計測した。左心房より容量 $0.8 \mathrm{ml}$ のバルーンカテーテルを左心室に挿入し left ventricular developed pressure (LVDP), $\mathrm{LV}_{\text {max }} \mathrm{d} p / \mathrm{d} t$ を測定した。冠灌流量は heart chamber 内へ滴下寸る冠流出液をメスシリンダ ーで採取し 1 分間量を測定した。

\section{6. 実 験 群}

\section{(1) 実験 I}

Cardioplegia を行わず冠灌流遮断中に心臓を

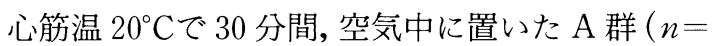
6)と FDA 中に浸漬したB群 $(n=6)$ で比較し た。

\section{（2）実験 II}

Cardioplegia として St. Thomas' solution を 3 分間注入後冠灌流遮断し, 心臓を何ら溶液に浸漬 せず $30^{\circ} \mathrm{C}$ に維持した heart chamber 内に 30 分間
置いた C 1 群 $(n=6), 30^{\circ} \mathrm{C}$ 生理食塩水 $(\mathrm{pH} 6.864$, $\left.\mathrm{PO}_{2} 168 \mathrm{mmHg}, \mathrm{PCO}_{2} 11.3 \mathrm{mmHg}\right)$ に浸漬した $\mathrm{C} 2$ 群 $(n=6)$, そして $30^{\circ} \mathrm{CFDA}$ に浸漬したC 3 群 $(n=6)$ について検討した. 各群とも遮断解除後 5 分ごとに LVDP, $\mathrm{LV}_{\text {max }} \mathrm{d} p / \mathrm{d} t$, 心拍数, 冠流 出量を測定し遮断前值に対する回復率を検討し た.

\section{7. 統計学的処理}

統計学的処理は Statsoft 社製のSTATISTICA で行った。各群の実験頭数は棄却検定後の 数であり，分散分析後に Student's $t$-test で有意 差の検定を行った.

\section{結果}

\section{1. 実 験 I}

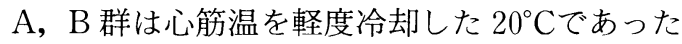
にもかかわらず，cardioplegia を施行しなかった ため冠灌流遮断後も拍動を続けたＡ 群は遮断後 $10 \pm 2$ 分間, B 群は $20 \pm 4$ 分間拍動した. A 群は再 灌流後心拍は再開せず心機能は回復しなかった。 これに比較し，FDA に浸漬した B 群は LVDP, $L V_{\max } \mathrm{d} p / \mathrm{d} t$, 心拍数, 冠流出量ともに良好に回 復した. 表 4 に再灌流後 15 分ごとの回復率を示し た。

\section{2. 実 験 II}

$\mathrm{C}$ 群では心筋温を $30^{\circ} \mathrm{C}$ したが St. Thomas' solutionによる cardioplegia で心停止を得た。

（1）LVDP の回復（図 2）

再灌流後 5 分値では C 1 群は $77.8 \pm 31.3 \%$ (mean土SD), C 2 群は 84.6 19.4\%であったが, しだいに低下し 60 分後にはC 1 群は $47.6 \pm 20.2 \%$, C 2 群は 39.9土6.7\%となった.C 1 群と C 2 群には有意差はなく図 2 に示すごとく回 復率は時間とともに下降した。これに対してC 3 群は再灌流後ただちに心拍を再開し 5 分後に $101.3 \pm 13.7 \%, 10$ 分後 $92.9 \pm 15.1 \%, 20$ 分後に は $92.9 \pm 15.1 \%$ を示し,この後 C 1 群, C 2 群に比 較し高い回復率を維持し有意差 $(p<0.01)$ を認め た.

（2） $L V_{\max } \mathrm{d} p / \mathrm{d} t$ (図 3)

$\mathrm{C} 1$ 群の再灌流 5 分の回復率は $73.6 \pm 30.7 \%$, C 2 群は $86.9 \pm 17.6 \%$, C 3 群は $103.9 \pm 24.2 \%$ で 
表 4 実験 1 ，再灌流後心機能の回復 $(\%)$

\begin{tabular}{|c|c|c|c|c|c|}
\hline \multicolumn{2}{|c|}{ After reperfusion } & $15 \mathrm{~min}$ & $30 \mathrm{~min}$ & $45 \mathrm{~min}$ & $60 \mathrm{~min}$ \\
\hline \multirow{2}{*}{$\begin{array}{l}\text { LVDP } \\
\text { (\% recovery) }\end{array}$} & group A & 0 & 0 & 0 & 0 \\
\hline & group B & $86.1 \pm 10.5$ & $72.2 \pm 20.1$ & $66.8 \pm 23.3$ & $58.1 \pm 23.9$ \\
\hline \multirow{2}{*}{$\begin{array}{l}\mathrm{LV}_{\max } \mathrm{d} p / \mathrm{d} t \\
(\% \text { recovery) }\end{array}$} & group A & 0 & 0 & 0 & 0 \\
\hline & group B & $80.2 \pm 20.5$ & $79.9 \pm 15.7$ & $65.8 \pm 27.6$ & $56.6 \pm 25.4$ \\
\hline \multirow{2}{*}{$\begin{array}{l}\text { Heart rate } \\
\text { (\% recovery) }\end{array}$} & group A & 0 & 0 & 0 & 0 \\
\hline & group B & $92.9 \pm 18.0$ & $96.9 \pm 12.5$ & $95.4 \pm 10.2$ & $93.8 \pm 12.3$ \\
\hline \multirow{2}{*}{$\begin{array}{l}\text { Coronary flow } \\
\text { (\% recovery) }\end{array}$} & group A & $80.1 \pm 11.6$ & $82.8 \pm 10.4$ & $38.8 \pm 6.6$ & $33.5 \pm 8.8$ \\
\hline & group B & $90.7 \pm 13.5$ & $81.4 \pm 7.6$ & $82.2 \pm 5.8$ & $78.8 \pm 3.1$ \\
\hline
\end{tabular}

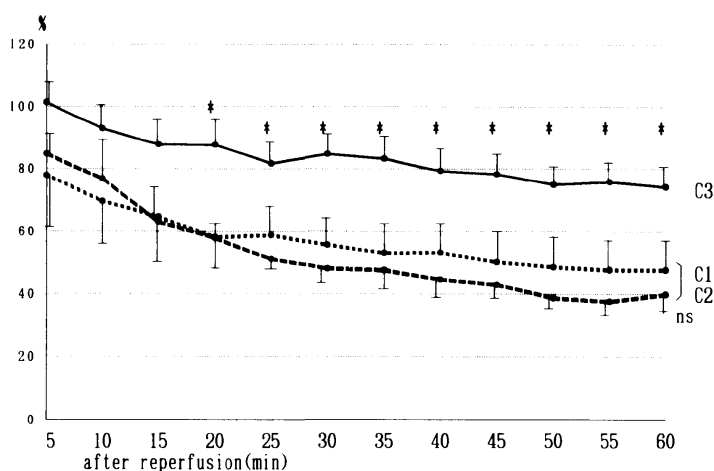

図 2 LVDP の回復率 $(\%)$

$* p<0.01$, C 3 vs C 2 , C 1 , ns : not significant

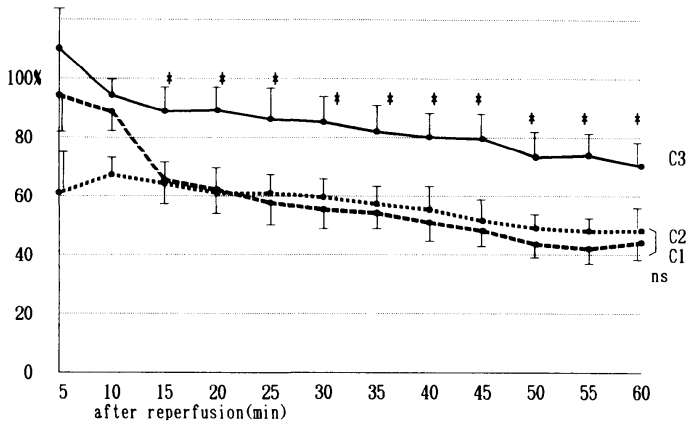

図 $3 \mathrm{LV}_{\max } \mathrm{d} p / \mathrm{d} t$ の回復率(\%)

$* p<0.01$, C 3 vs C 2 , C 1 , ns : not significant

あった. 15 分後から C 2 群, C 1 群は低下し始め C 3 群とのあいだに有意差 $(p<0.01)$ を認めた。 60 分後の測定ではC 3 群は $72.35 \pm 21.3 \%$ あった のに対し, C 2 群は $41.20 \pm 12.3 \%, C 1$ 群は $58.58 \pm 19.3 \%$ あっあっ。

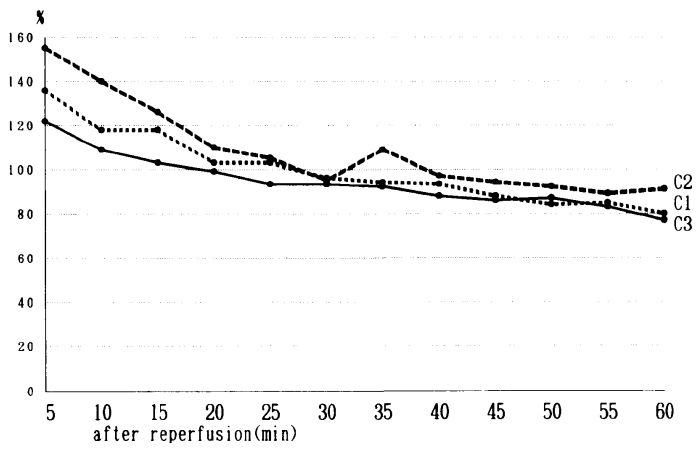

図 4 冠灌流量の回復率 $(\%)$

C 1 : C 2 : C 3 not significant

（3）冠流出量（coronary flow）（図 4) 冠流出量は再灌流直後から遮断前値を上回り, C 1 群の再灌流 5 分後は $136.6 \pm 26.97 \%, C 2$ 群 は $155.2 \pm 38.4 \%$ と最も多く, C 3 群は $121.9 \pm 17.7 \%$ あった。 その後 C 1 群，C 2 群は 低下し始め 60 分後にはC 1 群 $80.7 \pm 13.0 \%$, C 2 群 $90.8 \pm 21.4 \%$ となり 5 分值とのあいだに有意 差 $(p<0.01)$ を認めた.これに対し, C 3 群 60 分後 は $77.7 \pm 16.6 \%$ あり 5 分值とのあいだに有意 差がなく時間経過による低下は著明ではなかっ た。

\section{（4）心拍数（heart rate）（図 5)}

心拍数は再灌流前後值で著明な変化を示さず, 再灌流 5 分後の回復率は C 1 群 $100.3 \pm 8.9 \%$, C 2 群は $91.8 \pm 18.3 \%$ ，C 3 群は $94.7 \pm 18.5 \%$ で あった。 60 分後の測定でも C 1 群 $98.8 \pm 7.8 \%$ ， C 2 群 $94.7 \pm 14.7 \%$ ，C 3 群 99.2土15.3\%と時間 経過による低下は見られず，さらに各群間に有意 


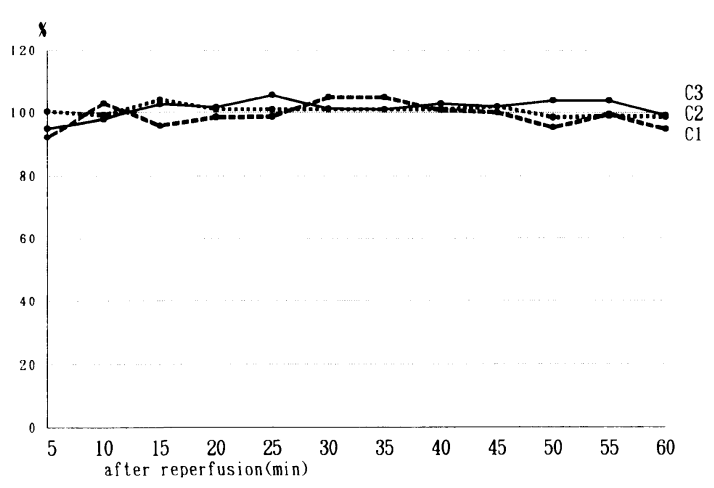

図 5 心拍数の回復率 $(\%)$

C 1 : C 2: C 3 not significant

差を認めなかった。

\section{考察}

Perfluorochemical (PFC) は優れた酸素運搬能 を有することから人工血液としての使用を目的に 研究開発された。初期に開発された perfluotributylamine はPFCのなかでもきわめ て高い酸素溶解度を有するが, 肝, 脾, 骨髄に蓄 積され体内半減期が約 900 日と長いため実用化さ れなかった perfluorodecalin (FDC) は半減期が約 7 日と臓器 内蓄積が少ない反面, 乳化しにくいという久点が あった。そこで，このFDCに乳化しやすい perfluorotripropylamine (FTPA) を 30\%混合し た乳剂 Fluosol ${ }^{\circledR}$-DA（FDA）が開発された ${ }^{5}$.

最近, 藏器移植への関心が高まり, 臟器保存の 灌流液として PFC の使用が検討され, 肝, 腎, 心 ${ }^{6)}$ において研究が行われている。移植における藏器 保存の目的で PFCを使用する場合は移植される までの間に灌流され, 移植直前には PFCをwashout するため体内に蓄積されることはない.しか し cardioplegic solutionとして用いる場合は循 環系への混入は避けられず体内蓄積による毒性が 問題となる.われわれ7 9) はこの FDA にカリウム を心停止剤として添加した oxygenated Fluosol cardioplegic solutionの心筋保護効果をラット摘 出灌流心において実験検討し良好な結果を得た が，体内蓄積の問題から臨床に応用しなかった。 しかしこの実験中に, 単純遮断群でしだいに拍動
が弱まり ischemic arrest となったラット心蔵を FDA 液に漬けると拍動が再開することを発見し た。これは低酸素状況下において, epicardium あ るいは endocardium を介して心筋が僅かに酸素 を取り込んだ可能性があると考えた。心筋細胞浮 遊液での実験や心筋細胞の培養, さらには心筋条 片を利用する実験の場合には, 酸素を吹送して酸 素化した栄養液に浸漬し組織や細胞に酸素を供給 しているわけであり，心臓全体をFDAに浸漬す るのとほぼ同様と思われる。

今回の実験でも cardioplegia を行わず単純遮 断後 FDA に浸漬した B 群が遮断中 $20 \pm 4$ 分間も 拍動を続けたのは, FDA から酸素を供給されたた めと考えられる。これに対し A 群は $10 \pm 2$ 分間拍 動したが，ついに心停止し再灌流後は全く拍動を 再開することはなかった。遮断中 $\mathrm{A}$ 群の 2 倍の時 間も拍動を続けた B 群は, 再灌流後拍動を再開 し, 15 分後の LVDP おょび $\mathrm{LV}_{\max } \mathrm{d} p / \mathrm{d} t$ は遮 断前值の約 $80 \%$ に回復した. しかし冠灌流遮断中 の拍動は,FDAにより非冠循環性に酸素が供給さ れているとはいえ，その他の収縮に必要なエネル ギー産生物質までが供給されているわけではな く, それら物質の枯渴から心拍動は次第に弱まっ て停止した。このような状況では虚血障害の発生 が考えられ，その虚血障害が再灌流後の後半（60 分後）に収縮力の回復率を $50 \%$ 台まで低下させた 原因と考えられた。

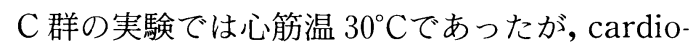
plegiaによって遮断後直ちに心停止が得られ, C 1, C 2, C 3 群とも遮断中に拍動を認めなかっ た.しかし C 1, C 2 群の再灌流後の左室機能回復 率はB 群と同様に後半には低下した. FDA に浸 漬した C 3 群の左室機能回復率が, 溶液に浸漬し ない C 1 群や生理食塩水に浸漬した C 2 群より有 意に良好で, 再灌流後半でも低下が軽度であった ことは, 迅速な心停止による高エネルギー物質の 保持だけでなく,FDAによる酸素の供給が高エネ ルギー物質の枯渇を抑制したと考えられた。

\section{結語}

軽度の心筋冷却 $\left(30^{\circ} \mathrm{C}\right)$ 下の心筋虚血において Perfluorochemicals（FDA）に心臓を浸漬した場 
合，心筋に対して非冠循環性に酸素を供給できる 可能性が示唆され，強度な心筋局所冷却に伴うさ まざまな障害の軽減に役立つと考えられた。

\section{文献}

1) Marco, J. D., Hahn, J. W. and Barner, H. B. : Topical cardiac hypothermia and phrenic nerve injury. Ann. Thorac. Surg. 23 : 235-237, 1977.

2) Esposito, R. A. and Spencer, F. C.: The effect of pericardial insulation on hypothermic phrenic nerve injury during open-heart surgery. Ann. Thorac. Surg. 43 : 303-308, 1987.

3) Allen, B. S., Buckberg, G. D., Rosenkranz, E. R., et al. : Topical cardiac hypothermia in patients with coronary disease. J. Thorac. Cardiovasc.
Surg. 104: 626-631, 1992.

4）光野孝雄：人工血流について. Med. Postgrad. 13: 373-388, 1975.

5）横山和正, 山内紘一, 大柳治正：ペルフルオロケ ミカルを利用した酸素輸液. 材料技術 2: 632638, 1984.

6）遠藤希彦, 長谷川隆光, 塩野元美ほか： Perfluorochemical を用いた心筋保存の実験的研 究. 臨床胸部外科 10 (Suppl. ) : 51-55, 1990.

7）野元成郎，井上恒一，堀内 誠ほか：心筋保護液 としての人工血液 (FDA-20\%, フルオゾール) の 利用. 呼と循 33 : 1355-1360, 1985.

8）野元成郎, 井上恒一, 渡辺俊明浪：人工血液 (FDA-20\%) と心筋保護. 人工臟器 15：410-413, 1986.

9）野元成郎：ラット摘出心による酸素加心筋保護 液の検討. 日胸外会誌 34：1627-1635, 1986. 